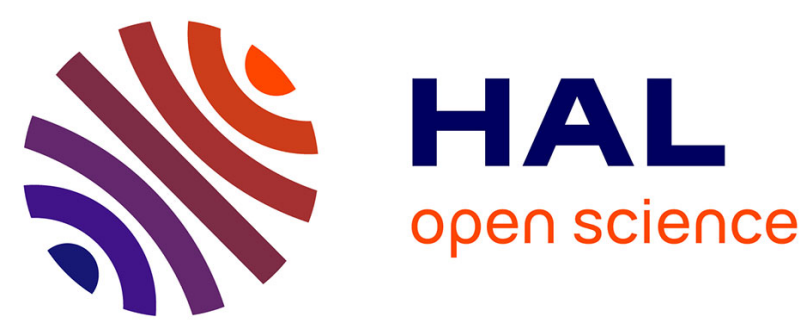

\title{
Perceived Risks and Benefits of Advanced Pay-Per-Use Type of Business Models Based on Industry 4.0 Enabled Technologies in Manufacturing Companies
}

\author{
Mikko Uuskoski, Karan Menon, Hannu Kärkkäinen, Kari Koskinen
}

\section{To cite this version:}

Mikko Uuskoski, Karan Menon, Hannu Kärkkäinen, Kari Koskinen. Perceived Risks and Benefits of Advanced Pay-Per-Use Type of Business Models Based on Industry 4.0 Enabled Technologies in Manufacturing Companies. 15th IFIP International Conference on Product Lifecycle Management (PLM), Jul 2018, Turin, Italy. pp.498-507, 10.1007/978-3-030-01614-2_46 . hal-02075602

\author{
HAL Id: hal-02075602 \\ https://hal.inria.fr/hal-02075602
}

Submitted on 21 Mar 2019

HAL is a multi-disciplinary open access archive for the deposit and dissemination of scientific research documents, whether they are published or not. The documents may come from teaching and research institutions in France or abroad, or from public or private research centers.
L'archive ouverte pluridisciplinaire HAL, est destinée au dépôt et à la diffusion de documents scientifiques de niveau recherche, publiés ou non, émanant des établissements d'enseignement et de recherche français ou étrangers, des laboratoires publics ou privés. 


\title{
Perceived risks and benefits of advanced pay-per-use type of business models based on Industry 4.0 enabled technologies in manufacturing companies
}

\author{
Mikko Uuskoski, Karan Menon ${ }^{\text {[0000-0001-9948-9659] }}$, Hannu Kärkkäinen ${ }^{\text {[0000-0003-4753-4416] }}$ \\ \& Kari Koskinen [0000-0002-8538-8184] \\ Tampere University of Technology, Finland \\ \{mikko.uuskoski, karan.menon, hannu.karkkainen, \\ kari.t.koskinen\} atut.fi
}

\begin{abstract}
There is a growing interest in the pay-per-outcome business models in manufacturing industries because of novel technologies provided by Industry 4.0 implementations. These business models for the software companies cannot be directly applied for manufacturing companies because of the scalability issues as well as complexity issues. The purpose of this paper is to identify perceived benefits and risks of Industry 4.0 enabled pay-per-outcome models for manufacturing companies (machine builders). We conducted qualitative interviews of machine building companies. We identified and selected companies that have been experimenting with novel Industry 4.0 enabled pay-per-outcome business models. We were able to create understanding the perceived benefits and risks of these advanced industry 4.0 enabled PPU/PPO type business models for machine builders. Since there is a limited amount of practical implications especially in case of investment heavy machine builders thus there is little understanding about related benefits and risks of implementing these novel Industry 4.0 enabled payper-outcome business models. This study can facilitate decision making of managers about implementing these novel business models by taking into account the expected benefits as well as bottlenecks encountered.
\end{abstract}

Keywords: Industry 4.0, Industrial Internet of Things, Business Models, Pay Per Use, Pay Per Outcome

\section{Introduction}

Services in product-oriented companies have grown to be one of the most active areas in research in the service research domain (e.g. [1]). There is a growing interest in novel types of business models in manufacturing industries because of the novel opportunities provided by technologies related to Industry 4.0 implementations. Pay-per-use (PPU) and pay-per-outcome (PPO) are some of the business models which have recently grown strongly in interest by researchers and practitioners alike. Some of the wellknown examples of such business models are, for example, Rolls Royce's "power by hour" business model [2], as well as Michelin's usage-based pay-per-kilometer or per- 
formance-based (pay-per-reduction in fuel consumption) models [3]. In machine building, these models would mean that instead of customers investing in and owning the production line machines and related software, they pay at least partly from the use or related valuable outcomes.

There is a multitude of research on PPU and PPO business models when it comes to the software companies [4], [5]. However, these business models for the software companies cannot be directly applied for manufacturing companies because of the scalability issues (selling software as a service can be much more easily offered and scaled up as a service than heavy investment products), as well as issues related to the complexity of machines (e.g. related to automation, electricity and mechanical hardware).

The purpose of this paper is to study PPU and PPO business models from the perspective of little studied SME-sized manufacturing companies (machine builders), instead of the huge companies, such as Rolls Royce and Michelin, and instead of the widely studied software companies' business models. Moreover, we presume, on the basis of our wide review of related literature, that there are no complete or $100 \%$ payper-outcome business models like in the software companies, that would allow us to compare or validate the research findings from software companies. Furthermore, we focus on Industry 4.0-enabled PPU and PPO models, which is still relatively little understood in academic literature. We aim to identify perceived benefits and risks of especially Industry 4.0 enabled pay-per-outcome models for manufacturing companies. Our main research question is: "What are the perceived benefits and risks of Industry 4.0 enabled PPU and PPO business models for machine building companies?

To study the above research question, we conducted qualitative interviews of machine building companies in the SME or close to SME category. In order to gain as useful information about the plans and implementations of these models, we identified and selected especially manufacturing companies that have been already experimenting with novel Industry 4.0- enabled business models, such as PPU and PPO models. We thus expect the companies to give us in-depth insights on the PPU and PPO business model related benefits as well as risks because of their experience and use of Industry 4.0 based technologies. Most of the companies that are planning or experimenting with these novel business models are yet in the very early phases of the implementation of these novel Industry 4.0 enabled pay-per-outcome business models. The remainder of the paper is divided into theoretical background, research methodology and design, results and findings, discussion and conclusions.

\section{Theoretical Background}

\subsection{Industry 4.0 technologies}

Industry 4.0/Industrial Internet can be defined as industrial systems that integrate computational and physical capabilities of machines in order to provide advanced real time or near real time analytics and interact with humans. [6]-[9] The application or use of Industry 4.0/Industrial Internet in the real world is possible due to the integration of several enabling or key technologies. 


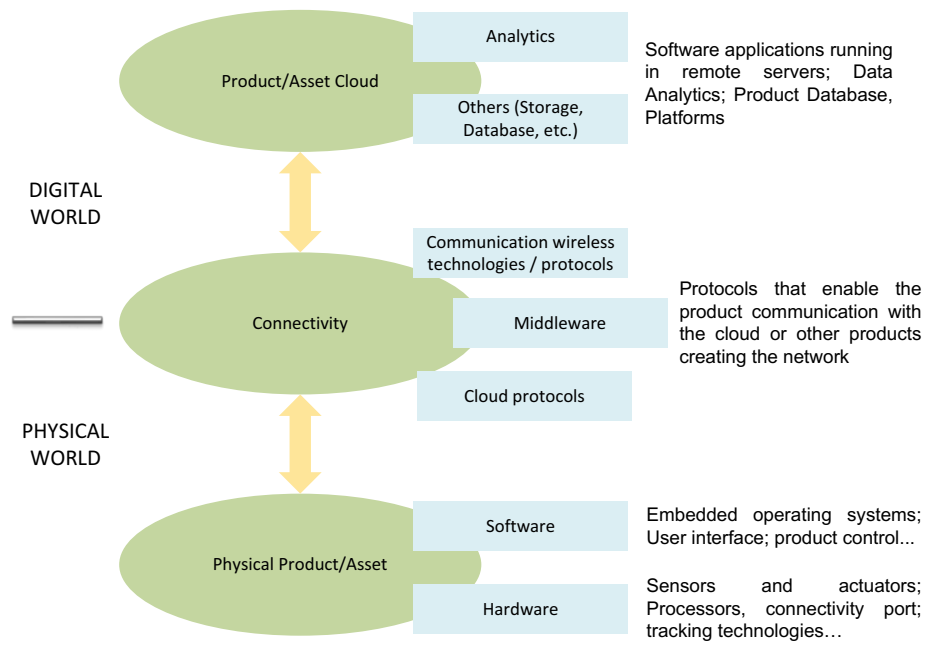

Fig. 1. Industrial Internet technology stack. Adapted from [10]

These enabling technologies can be divided into three core elements in the form of a technology stack as shown in fig. 1; physical product/asset, connectivity and product/asset cloud. The first one, physical product/asset, is divided into two subcategories, Software and Hardware which contain technologies such as sensors and actuators, and embedded operating systems respectively. Connectivity category refers to protocols and technologies that enable the product communication with the cloud or other products creating the network [11] and connecting the physical with the digital world. It has been divided into three subcategories: Internet protocols (e.g. IPv4 and IPv6), Middleware and Communication technologies and protocols such as RFID, NFC among others. Finally, the Product/Asset Cloud category refers mainly to software applications running in remote servers, data analytics, platforms, etc. It has been split into two subcategories: Analytics and a generic one named. Others conformed by technologies for storage, database, etc.

\subsection{Industry 4.0 enabled advanced business models}

As far as the Industrial Internet/Industry 4.0 technologies are concerned the impact is not only restricted to production-technical change but also towards extensive organizational changes and benefits [12], [13]. These organizational benefits result into influencing the business model of the manufacturing company. Hence, the only way to make the most of the emergence of industry 4.0 based technologies to adapt new business models (such as pay-per-use, pay-per-outcome) or to innovate the existing business models [10], [12], [14]. Literature has discussed about these business models by using tools like the business model canvas for some industries specifically but also very broadly covering the manufacturing sector. [13]-[15] 
Industrial Internet/industry 4.0 technologies bring in the advantages related to real time or near real time connectivity of machines over the cloud that can result into advanced analytics of the condition of the machine as well as the process optimization related issues. This kind of technological advancement can give rise to new business models such as the pay per use [12] and pay per outcome [16] type of advanced business models. The primary idea behind these novel advanced business models is to move the risk from the customer end to the manufacturer's end and as a result building on earnings and profit for the manufacturer.

In case of machine builders or production line manufacturers, their business is dependent on the investment heavy product, that would be a machine or a production line. [17] In order to implement Industry 4.0 enabled novel business models such as the payper-use for example, it is important for the machine builder to strategize the implementation of the new business model in a hybrid manner, where the equipment can be rented or leased and the added Industry 4.0 enabled services can be sold to the customer based on the customer's use. [12]

\subsection{Benefits and risks of Ind. 4.0 enabled advanced business models}

Industry 4.0 technologies in themselves bring a lot of benefits and risks to production and manufacturing related processes as well as to the business models of the companies that use these advanced technologies. Literature has documented these Industry 4.0 technologies' related benefits and risks very well. [10], [18], [19] But there is a scarcity of research related to the implications of these advanced business models (PPU/PPO) that are enabled by industry 4.0. In general, there is research which discusses the technology related enablers or hindrances that industry 4.0 technologies can have on the implementation of advanced business models [12], [13].

Implications, benefits and risks, of these advanced business models (PPU/PPO) enabled by industry 4.0 technologies will benefit manufacturing companies both small and large companies. Benefits and risks of advanced business models need to be evaluated from internal, market (customer and competition) and shareholder's perspective in order to get a full picture of the potential impacts of these business models.

\section{$3 \quad$ Research methodology and design}

The aim of this research is to understand the benefits and risks of advanced business models, such as PPU and PPO enabled by Industry 4.0 technologies. To study this, we conducted qualitative interviews of three machine building companies in the SME or close to SME category. In order to gain as useful information about the plans and implementations of these models, we identified and selected especially manufacturing companies that have been already experimenting with novel industry 4.0 - enabled business models, such as PPU and PPO models. We thus expect the companies to give us in-depth insights on the PPU and PPO business model related benefits as well as risks because of their experience and use of Industry 4.0 based technologies. Following com- 
panies were selected because they have used Industry 4.0 based technologies to implement PPU business model to a certain extent. They are all machine builders who specialize in manufacturing systems and production lines.

The details of the companies after anonymizing explicit information is as follows:

\section{Company A}

The turnover level for company A is $100-150$ million $€$ and the range of number of employees is 200-500. Company supplies machines and systems for sheet metal related operations. Their manufacturing facilities are in Europe, North America and Asia. Their sales and service network is present in over 80 countries.

\section{Company B}

The turnover level for company B is 50-100 million $€$ and the range of number of employees is 200-500. The main customer segments are engineering and machine building industries, aircraft and aerospace industries, manufacturers of construction and mining machinery, parts manufacturing and assembly.

\section{Company C}

The turnover level for company $\mathrm{C}$ is $100-150$ million $€$ and the range of number of employees is 200-500. Company's operations are divided into the Machines and Services business areas. Machines business product portfolio covers a wide and technologically advanced range of building material processing Services business provides machine maintenance services, machine upgrades and modernizations, spare parts and the tools.

The main themes of the questionnaire that was used to collect the qualitative data is as follows: Implementation of Industry 4.0 and the significance of Industry 4.0 in their business.

1. Types of PPU/PPO models that the companies have implemented or plan to implement.

2. Benefits and Risks of Industry 4.0 enabled advanced business models such as PPU/PPO type business models.

We had roughly 60 to 80 minutes of discussion with the experts who are responsible for implementing Industry 4.0 based technologies and related strategy and business model development.

\section{$4 \quad$ Results and findings}

In this section, we present results and findings from the three interviewed companies. First, we present the results related to the significance of Industry 4.0 based technologies in implementing the advanced business models such as PPU/PPO. Finally, we present our findings on perceived benefits and risks of these advanced business models in Table 1 and 2. 
The three companies share their views on the significance of Industry 4.0 based technologies in the advanced business models such as the PPU/PPO in the following manner: company A: The data from the machines is stored into the cloud., which is then converted into useful information using advanced analytics using Industry 4.0 based technologies, and sold to the customer using the PPU model. Company B: Industry 4.0 technologies are vital for two purposes, one for digitalization of manufacturing processes and second to create PPU based services for example automatic order management type PPU services. And company C: For the more advanced business model like the pay per outcome or outcome as a service, it will be very important to have the Industry 4.0 based technologies to increase the integration from machine level to ERP level.

Table 1. Benefits of PPU Business Model

\begin{tabular}{|c|c|c|c|}
\hline & Company A & Company B & Company $\mathrm{C}$ \\
\hline Internal & $\begin{array}{l}\text { There is a benefit and } \\
\text { motivation that PPU } \\
\text { BM brings in terms of } \\
\text { combining Data, AI } \\
\text { and own know-how in } \\
\text { new ways }\end{array}$ & $\begin{array}{l}\text { PPU BM helps in get- } \\
\text { ting new deals faster } \\
\text { than the competing } \\
\text { companies. }\end{array}$ & $\begin{array}{l}\text {-The benefit of this } \\
\text { kind of PPU BM when } \\
\text { compared to the tradi- } \\
\text { tional BM is that it will } \\
\text { enable continuous turn- } \\
\text { over and eventually } \\
\text { build on the profits. }\end{array}$ \\
\hline Market related & $\begin{array}{l}\text {-The benefit of the } \\
\text { PPU BM is that it rein- } \\
\text { forces the position of } \\
\text { the company as a tech- } \\
\text { nology leader and } \\
\text { eventually makes it } \\
\text { stronger. } \\
\text {-The benefit of PPU } \\
\text { BM is that it can help } \\
\text { the company compete } \\
\text { with competitors who } \\
\text { sell the equipment at a } \\
\text { lower price. They can } \\
\text { do this by putting more } \\
\text { intelligence in the ma- } \\
\text { chines by PPU BM } \\
\text { based services. }\end{array}$ & $\begin{array}{l}\text {-The benefit of the } \\
\text { PPU BM is that it al- } \\
\text { lows faster deals to } \\
\text { happen with the cus- } \\
\text { tomers and eventually } \\
\text { it gives a competitive } \\
\text { edge to the company. } \\
\text {-The PPU BM also } \\
\text { makes sure that the } \\
\text { customers get the ad- } \\
\text { vanced services } \\
\text { quickly or rather im- } \\
\text { mediately } \\
\text {-Customer sees the } \\
\text { benefit for the PPU } \\
\text { BM if the company } \\
\text { sells functionalities } \\
\text { like, automated order- } \\
\text { ing (automatic order } \\
\text { management)-it can } \\
\text { save person months for } \\
\text { the customer }\end{array}$ & $\begin{array}{l}\text {-The benefit of PPU } \\
\text { BM is that it will allow } \\
\text { them to move to Out- } \\
\text { come based models } \\
\text { quickly. } \\
\text {-The added benefit of } \\
\text { PPU BM is that it will } \\
\text { allow the company to } \\
\text { keep the advanced } \\
\text { software and services } \\
\text { updated all the time at } \\
\text { the customer end. }\end{array}$ \\
\hline Shareholder related & $\begin{array}{l}\text { Major shareholder is } \\
\text { forcing them towards } \\
\text { the PPU kind of new } \\
\text { BMs because they see } \\
\text { the benefits towards } \\
\text { growth in these BMs } \\
\text { i.e. it improves the } \\
\text { profit margin for the } \\
\text { shareholders }\end{array}$ & - & $\begin{array}{l}\text {-The benefit of this } \\
\text { kind of a PPU model is } \\
\text { that it will allow con- } \\
\text { tinuous turnover and } \\
\text { eventually build on the } \\
\text { profits. }\end{array}$ \\
\hline Others & - & - & - \\
\hline
\end{tabular}


In Table 1., above we present the results and finding based on benefits of PPU business model for the interviewed companies. The logic used to distribute the perceived benefits as well as risks was to distribute them in internal, market related, shareholder related and others.

Table 2. Risks of PPU Business Model

\begin{tabular}{|c|c|c|c|}
\hline & Company A & Company B & Company C \\
\hline Internal & $\begin{array}{l}\text {-PPU business model } \\
\text { must have defined cer- } \\
\text { tain service quality } \\
\text { level and if the deliv- } \\
\text { ery doesn't meet prom- } \\
\text { ised level customer re- } \\
\text { quires compensation. } \\
\text {-Internal sales need to } \\
\text { educate the customers } \\
\text { about the advantages } \\
\text { of PPU BM or the risk } \\
\text { is customers do not be- } \\
\text { lieve in advantages } \\
\text { of PPU business } \\
\text { model. }\end{array}$ & $\begin{array}{l}\text {-PPU BM is a risk if it } \\
\text { does not contribute to } \\
\text { the overall sales in a } \\
\text { significant manner. }\end{array}$ & $\begin{array}{l}\text { Internal Mind-set in } \\
\text { the sales organization, } \\
\text { because they still pre- } \\
\text { fer turnover from hard- } \\
\text { ware sales as the most } \\
\text { important factor in- } \\
\text { stead of PPU sales. }\end{array}$ \\
\hline Market related & $\begin{array}{l}\text {-The new service/soft- } \\
\text { ware system which } \\
\text { could be under PPU } \\
\text { business model is not } \\
\text { good enough to show } \\
\text { correct data and infor- } \\
\text { mation at this point and } \\
\text { hence the risk is the } \\
\text { customer might not } \\
\text { pay for it. }\end{array}$ & $\begin{array}{l}\text {-Forcing the PPU } \\
\text { model on the customer } \\
\text { can create a risk of los- } \\
\text { ing the deal or the cus- } \\
\text { tomer. (Implication is) } \\
\text { Sales process should } \\
\text { be synchronized with } \\
\text { the customer mind-set. } \\
\text {-Customer gets scepti- } \\
\text { cal about the hardware } \\
\text { if the PPU BM only } \\
\text { sells machine/hardware } \\
\text { related simple added } \\
\text { services and that is a } \\
\text { risk. }\end{array}$ & $\begin{array}{l}\text {-Customer finds that } \\
\text { PPU billing is difficult } \\
\text { hence they have to } \\
\text { agree for a new smart } \\
\text { type of contract. } \\
\text {-The risk for a PPU } \\
\text { BM related to services } \\
\text { is that it is intangible } \\
\text { and customers might } \\
\text { not realize the benefits } \\
\text { like they would in case } \\
\text { of a tangible product. }\end{array}$ \\
\hline Shareholder related & - & - & $\begin{array}{l}\text { Business model re- } \\
\text { quires patience from } \\
\text { the shareholders be- } \\
\text { cause the outcomes/re- } \\
\text { sults are not immedi- } \\
\text { ate. }\end{array}$ \\
\hline Others & - & $\begin{array}{l}\text {-If the advanced leas- } \\
\text { ing contract will be im- } \\
\text { plemented, who will be } \\
\text { responsible for a } \\
\text { needed capital? } \\
\text {-There will be more } \\
\text { layers between ma- } \\
\text { chine builder and cus- } \\
\text { tomer, which can leave } \\
\text { space to new actors, } \\
\text { who will take bargain- } \\
\text { ing power. }\end{array}$ & $\begin{array}{l}\text { The competition will } \\
\text { implement PPU Busi- } \\
\text { ness Models offering } \\
\text { faster. }\end{array}$ \\
\hline
\end{tabular}


Table 2 presents findings related to the perceived risks that the respondents pointed out towards the Industry 4.0 enabled advanced business models, such as the PPU/PPO type business models. Based on these results and findings we discuss the major conclusions as well as managerial implications in the next section.

\section{Discussion and conclusions}

We aimed to answer to the main research question "What are perceived benefits and risks of Industry 4.0 enabled pay per outcome business models for machine building companies?" This study will provide academic novelty by creating new understanding about the possibilities and limitations of Industry 4.0- enabled advanced business models in SME-sized machine builders operating in production line machine building and in investment heavy businesses, the models being hybrid models between traditional and PPU/PPO models. Existing empirical qualitative studies have not identified benefits and risks of Industry 4.0 enabled pay-per-outcome business models in the above types of machine building companies.

From the perspective of identified advanced business models (PPU/PPO), the Industry4.0- enabled technologies played a pivotal role in all the studied manufacturing companies. This was true from two different perspectives: both them being able to support the digitalization of manufacturing-related processes, such as monitoring and controlling the manufacturing process in new ways, and the order management process, and them enabling the creation of new PPU-based services, such as remote monitoring and automatic order management.

First, we found that the studied companies had the PPU component in their business model repertoire (two had already implemented it, and one said that they would soon implement it). In addition, all of them were currently thinking of including also the PPO type of advanced business model in the near future, the planning being already very far. More concretely, two companies were found to already have a relatively concrete plan towards outcome based (PPO) business models, and the third one was planning to go there, as well, if the capital will be provided to the customers of the advanced leasing model by a third party. Furthermore, at least one of the companies was able to already define their outcome in the above PPO model as delivery reliability.

Concerning the perceived benefits, we were able to recognize internal, market-related as well as shareholder- related benefits. All companies saw that PPU business model components were beneficial for them from the strategic perspective to e.g. allow new sources for growth, while earnings from mere hardware and traditional services was seen to be getting more and more difficult, and for other ways of gaining competitive advantage. In overall, we found that PPU and PPO type of business models were genuinely interesting for the studied machine building companies because of the strategic and the other mentioned benefits. In more detail, even if there were some similarities in perceived benefits, when going more into detail, it seemed that the expressed perceived benefits were relatively unique to the companies, and it seemed to be the core business, their unique features in machine building, and the related markets that fundamentally impacted the perceived benefits. 
Concerning the perceived risks, all companies saw that there were also clear and important risks related to the customer understanding and the acceptance of the advanced PPU models.

Some of the risks were expressed to be of a "show-stopper" type: these included, internally, for instance that the mindset of sales towards the advanced PPU/PPO models had to be strongly changed before more fully implementing the new models (i.e. those related to the current selling of tangible goods instead of selling of use or outcome). Furthermore, one of the companies considered that the capital related to the purchase of the hardware/machines required essentially a third party in the planned advanced leasing model because of the large required machine investments, or else the PPU model would not be implemented. As one important further risk towards the implementation was the need of shareholders to change their traditional view towards their profit expectations, because the returns of PPU/PPO models would take more time to develop compared to the traditional investment-oriented model.

This study can facilitate decision making of managers about implementing these advanced business models by taking into account the expected benefits as well as risks and potential bottlenecks encountered. As for further managerial implications, in order to establish novel types of PPU/PPO business models enabled by Industry 4.0, managers should make sure that there is clear product strategy also for the pay-per-use-type of products and services. They should also be able to make customers to understand and be guaranteed for what they would be getting by the novel business models. For instance, detailed long term break-even calculations should be carried out for customers, while they should also be quite concrete and realistic. Furthermore, it should be made sure that especially the first launched products making use of new PPO/PPU business models will be clearly defined and are clearly selected so that they can be shown to be valuable to the customers.

Considering the limitations of this study and future research, the possibilities of actual PPO models should be further studied in various types of especially SME-sized manufacturing companies, while our studied companies had not yet implemented such models, and while there are very few earlier academic studies that have studied PPO models in such contexts. Second, we would like to extend our study to include respondents from several company viewpoints to include e.g. CEO and managing director levels, as well as persons responsible for automation technology and IT. Furthermore, since the transition to such advanced business models is not an easy one in manufacturing companies, it would be important to research how the overall transition to implementing such business models can be done, what kinds of novel competences and capabilities are needed for implementing PPU/PPO models in the case of SME machine builders, and what different types of concrete options a machine builder could have concerning the designing of hybrid PPU/PPO business models.

\section{References}

[1] A. L. Ostrom et al., "Moving forward and making a difference: Research priorities for the science of service," J. Serv. Res., vol. 13, no. 1, pp. 4-36, Feb. 2010.

[2] H. Gebauer, C. J. Saul, M. Haldimann, and A. Gustafsson, "Organizational capabilities 
for pay-per-use services in product-oriented companies," Int. J. Prod. Econ., 2016.

[3] H. Gebauer, S. Joncourt, and C. Saul, "Services in productoriented companies: Past, present, and future [Servicios en empresas orientadas a productos: Pasado, presente y future]," Universia Bus. Rev., vol. 2016, no. 49, pp. 32-53, 2016.

[4] L. M. Vaquero, L. Rodero-Merino, J. Caceres, and M. Lindner, "A break in the clouds," ACM SIGCOMM Comput. Commun. Rev., vol. 39, no. 1, p. 50, Dec. 2008.

[5] P. C. Fishburn and A. M. Odlyzko, "Competitive pricing of information goods: Subscription pricing versus pay-per-use," Econ. Theory, vol. 13, no. 2, pp. 447-470, Feb. 1999.

[6] M. Hermann, T. Pentek, and B. Otto, "Design Principles for Industrie 4.0 Scenarios," in 2016 49th Hawaii International Conference on System Sciences (HICSS), 2016, pp. 3928-3937.

[7] I. Lee and K. Lee, "The Internet of Things (IoT): Applications, investments, and challenges for enterprises," Bus. Horiz., vol. 58, no. 4, pp. 431-440, Jul. 2015.

[8] P. C. Evans and M. Annunziata, "Industrial internet: Pushing the boundaries of minds and machines." General Electric, 2012.

[9] K. R. Iansiti, M., Lakhani, "Digital Ubiquity. How Connections, Sensors, and Data Are Revolutionizing Business," Harv. Bus. Rev., vol. 92, no. 11, pp. 90-99, 2014.

[10] J. Heppelmann, M. E. Porter, and J. E. Heppelmann, "How Smart, Connected Products Are Transforming Competition," Harv. Bus. Rev., vol. 92, no. 11, 2014.

[11] M. E. Porter and J. E. Heppelmann, "How smart, connected products are transforming competition," Harv. Bus. Rev., vol. 92, no. 11, pp. 64-88, 2014.

[12] H. Gebauer, C. J. Saul, M. Haldimann, and A. Gustafsson, "Organizational capabilities for pay-per-use services in product-oriented companies," Int. J. Prod. Econ., 2015.

[13] C. ARNOLD, D. KIEL, and K.-I. VOIGT, "HOW THE INDUSTRIAL INTERNET OF THINGS CHANGES BUSINESS MODELS IN DIFFERENT MANUFACTURING INDUSTRIES, ”Int. J. Innov. Manag., vol. 20, no. 8, p. 1640015, Dec. 2016.

[14] S. M. LAUDIEN and B. DAXBÖCK, "THE INFLUENCE OF THE INDUSTRIAL INTERNET OF THINGS ON BUSINESS MODEL DESIGN: A QUALITATIVEEMPIRICAL ANALYSIS, ”Int. J. Innov. Manag., vol. 20, no. 8, p. 1640014, Dec. 2016.

[15] M. Ehret and J. Wirtz, "Unlocking value from machines: business models and the industrial internet of things," J. Mark. Manag., vol. 33, no. 1-2, pp. 111-130, Jan. 2017.

[16] S. Gierej, "Techniques for designing value propositions applicable to the concept of outcome-economy," Eng. Manag. Prod. Serv., vol. 9, no. 1, p. 56, Jan. 2017.

[17] G. Copani, S. Marvulli, and L. M. Tosatti, An innovative pattern to design new business models in the machine tool industry, vol. 266. Boston, MA: Springer US, 2008.

[18] P. D. H. Kagermann, "Change Through Digitization-Value Creation in the Age of Industry 4.0,” H. Albach, H. Meffert, A. Pinkwart, and R. Reichwald, Eds. Springer Fachmedien Wiesbaden, 2015, pp. 23-45.

[19] K. Menon, H. Kärkkäinen, and L. Lasrado, "TOWARDS A MATURITY MODELING APPROACH FOR THE IMPLEMENTATION OF INDUSTRIAL INTERNET," PACIS 2016 Proc., 2016. 